\title{
A Quarrel at the Beer Shop of Little Memphis and a Murder
}

\author{
Gert Baetens \& Willy Clarysse*
}

\begin{abstract}
Petition by an Egyptian woman to the king concerning an argument at the beer shop in the Arsinoite village of Memphis (recto); fragmentary report about a murder case (verso).
\end{abstract}

Keywords: petition, enteuxis, women, hybris, murder

DOI 10.1515/apf-2016-0026

The Petrie papyri collection of Trinity College Dublin holds several fragments of Ptolemaic petitions that have not been published in the P.Petrie volumes. One of the better preserved petitions, Pap. Gr. env. 127, has recently been published by Baetens. ${ }^{1}$ Among the other unpublished texts, Pap. Gr. env. 86/87 consists of two considerable fragments containing writing on both the recto and verso, joined by Clarysse. The recto, written across the fibres, bears an enteuxis by a woman to the king dated to 232 BC (cf. infra) concerning an argument at the beer shop of Memphis in the Arsinoite nome that ended up with a fight. ${ }^{2}$ On the verso, three columns of

Vorbemerkung: Cf. TM 8832 (recto) \& 8831 (verso). We would like to thank Prof. Brian McGing and the staff of the Manuscripts \& Archives Research Library of Trinity College Dublin for their support during the consultation of the original papyrus, and the Board of Trinity College for their permission to publish this text.

" Kontakt: Gert Baetens, Katholieke Universiteit Leuven, Faculteit Letteren, Onderzoekseenheid Geschiedenis, Onderzoeksgroep Oude Geschiedenis, Erasmushuis, Blijde Inkomststraat 21, B-3000 Leuven, Belgien, <gert.baetens@arts.kuleuven.be>; Willy Clarysse, Katholieke Universiteit Leuven, Faculteit Letteren, Onderzoekseenheid Geschiedenis, Onderzoeksgroep Oude Geschiedenis, Erasmushuis, Blijde Inkomststraat 21, B-3000 Leuven, Belgien, <willy.clarysse@kuleuven.be>.

${ }^{1}$ G. Baetens, 'A petition to the epimeletes Dorotheos in Trinity College Dublin', Ancient Society 44 (2014), pp. 91-104.

${ }^{2}$ For violent disputes involving women in petitions, see M. Parca, 'Violence by and against Women in Documentary Papyri from Ptolemaic and Roman Egypt', in: H. Melaerts 
text, written upside down along the fibres, seem to constitute an official report about a murder case. ${ }^{3}$ Since the names of the disputing parties on the recto do not match the names on the verso, the two texts are clearly not directly connected. The strategos Aphthonetos seems to have been involved in both cases, however, which may account for the co-appearance of these two communications on the same papyrus. ${ }^{4}$

Fragment A, which contains the left-hand side of the texts, measures $7.5 \mathrm{~cm}(\mathrm{H}) \times 14 \mathrm{~cm}(\mathrm{~W})$; parts of its upper, lower and left-hand margin have been preserved. Fragment B, which contains most of the right handside, measures $7.5 \mathrm{~cm}(\mathrm{H}) \times 14.5 \mathrm{~cm}(\mathrm{~W})$; parts of its upper and lower margin have been preserved, but on its right-hand side a stretch of ca. 2-3 $\mathrm{cm}$ of papyrus has gone lost (cf. the transition of $11.1-2,2-3,7-8$ and 910 on the recto). In some places, the two fragments seem to join, but on other lines a couple of signs have clearly disappeared in the break. ${ }^{5}$ Originally, the document was ca. 31-32 cm wide, covering the normal height of a papyrus roll. Although most of the papyrus has been preserved, both sides are difficult to read: much of the text has faded and in several places the document has been damaged and/or smudged with ink. On the verso, some pieces of plaster are still sticking to the surface.

The texts on the recto and verso are the work of different scribes: both are written in a small, well-trained and neat hand, but minor differences can be noted, e.g. the upper strokes of the chi are flattened on the recto but not on the verso, and the right leg of the pi goes up higher on the recto than on the verso. The petition on the recto was the primary text: it is written transversa charta, like most enteuxeis to the king that have been

\& L. Mooren (eds.), Le rôle et le statut de la femme en Égypte hellénistique, romaine et byzantine (Studia Hellenistica 37), Leuven 2002, pp. 283-296; E. Scheerlinck, 'Inheritance disputes and violence in women's petitions from Ptolemaic Egypt', Papyrologica Lupiensia 20-21 (2012), pp. 163-176.

${ }^{3}$ For homicide in Greco-Roman Egypt, see B. Baldwin, 'Crime and Criminals in Graeco-Roman Egypt', Aegyptus 43 (1963), pp. 259-260; A. Helmis, Crime et châtiment dans l'Égypte ptolémaïque: recherches sur l'autonomie d'un modèle pénal [dissertation Université Paris Ouest Nanterre La Défense], Paris 1986; R. Taubenschlag, The law of Greco-Roman Egypt in the light of the papyri 332 B.C.-640 A.D., second edition, Warzaw 1955, pp. 431-434.

${ }^{4}$ This papyrus may well belong to Aphthonetos' archive, like other texts from the Petrie papyri collection: cf. TM Arch 400; K. Vandorpe, W. Clarysse \& H. Verreth, GraecoRoman archives from the Fayum, Leuven 2015, p. 65.

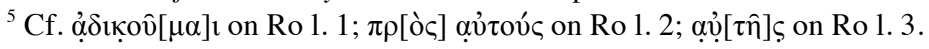


preserved. ${ }^{6}$ The text on the verso is a draft (as becomes clear from the numerous corrections) and was added at a later stage.

\section{Transcription}

\section{Recto}

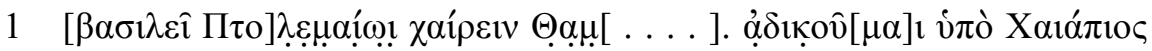

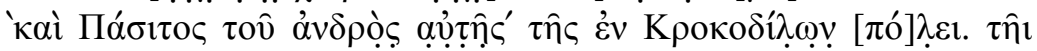
$\gamma \grave{\alpha} \rho \bar{\zeta} \tau[\mathrm{ov}]$

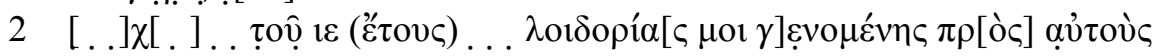

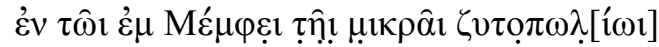

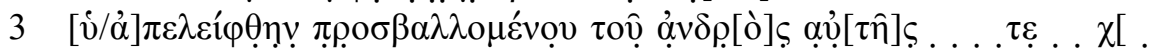

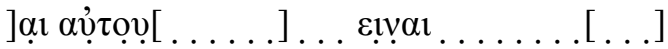

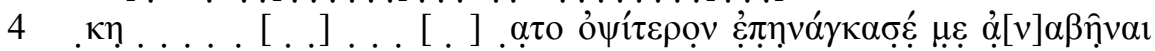

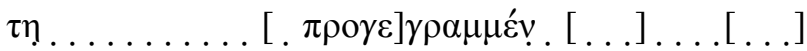

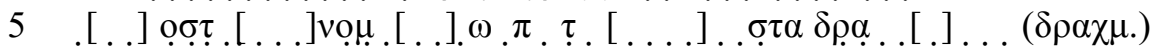

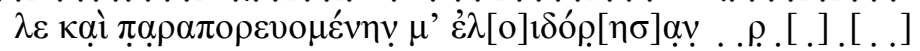

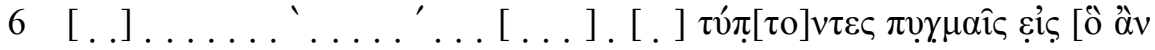

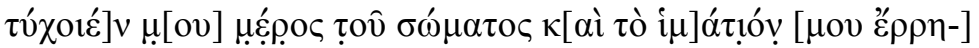

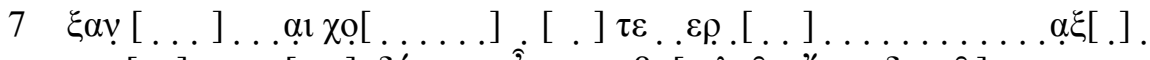

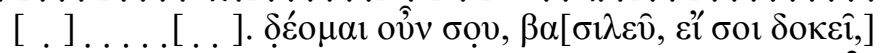

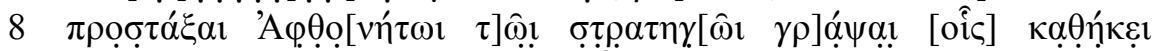

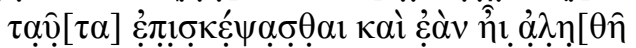

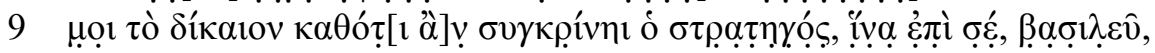

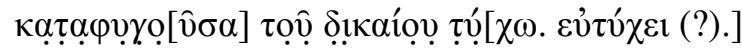

Verso col. I

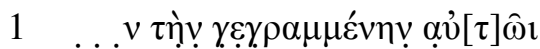

2 [.]. . . . . к $\alpha \tau \omega \mathrm{c} . \kappa \alpha \dot{\lambda} \hat{\omega} \varsigma$ ơิv

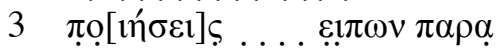

Traces of five more lines that are completely illegible. There is a vacat between 11. 5-6.

\footnotetext{
${ }^{6}$ For the material particularities of enteuxeis to the king, see O. Guéraud, ENTEY $\Xi E I \Sigma$ : requêtes et plaintes adressées au roi d'Égypte au IIIe siècle avant J.C., Cairo 1931, pp. xvii-xxii.
} 


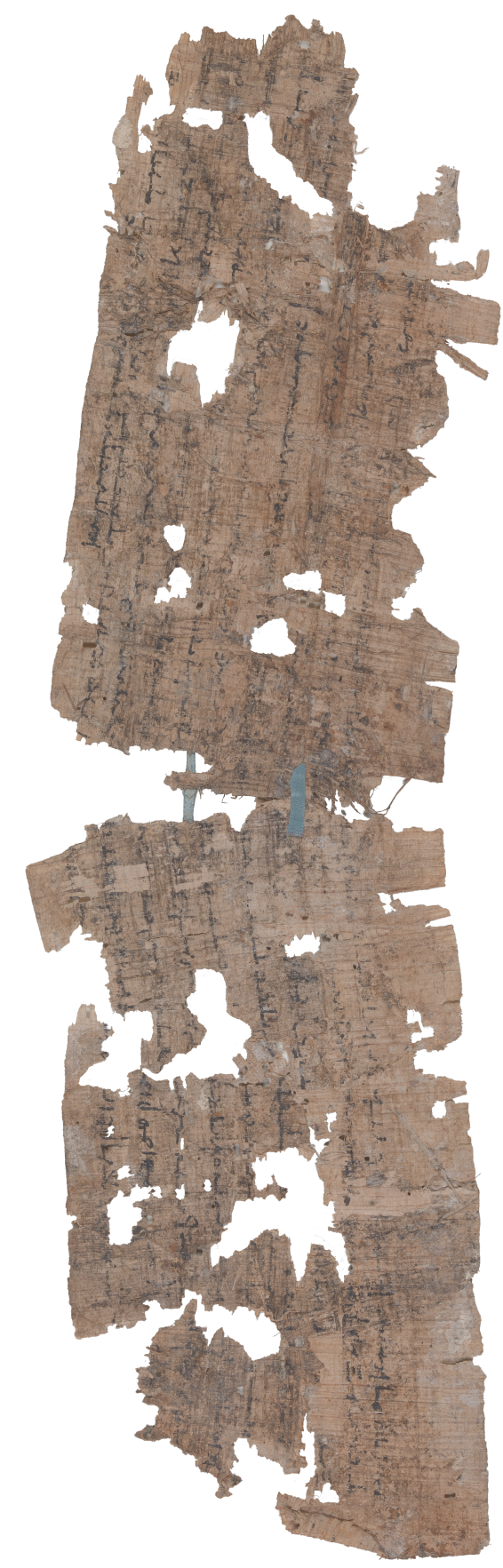

Recto

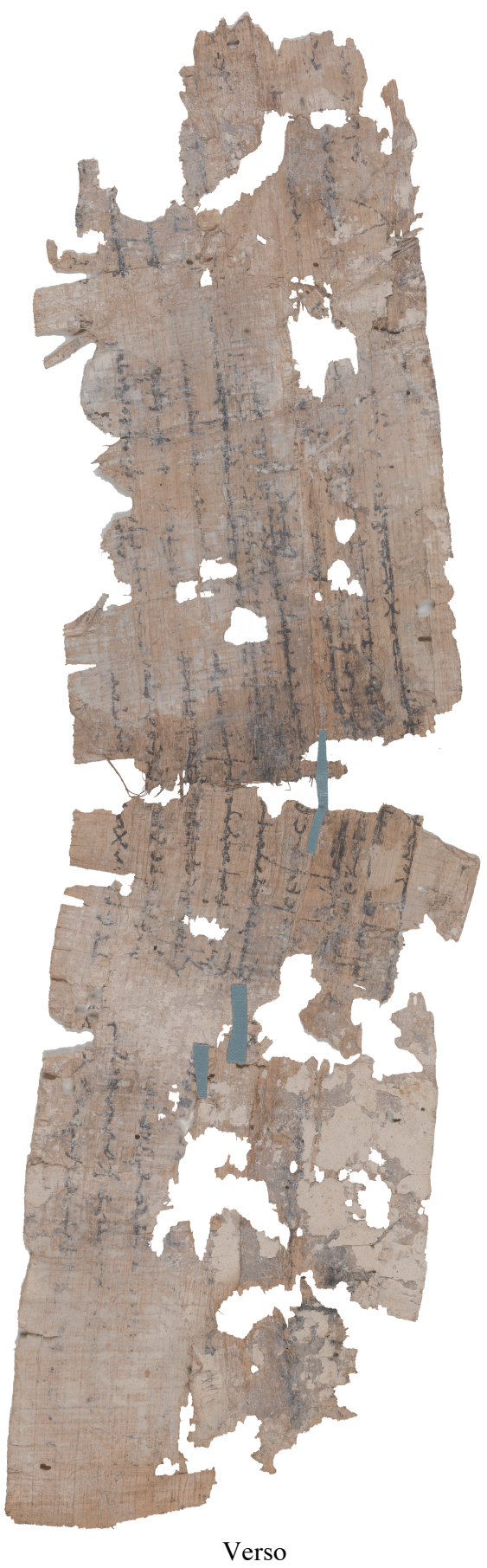




\section{Verso col. II}

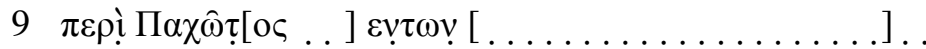

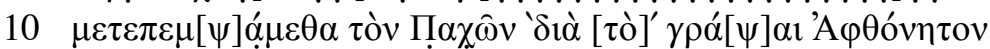

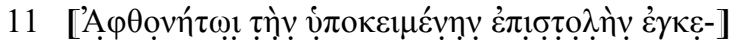

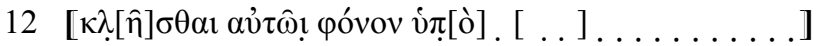

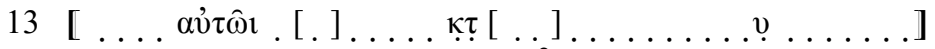

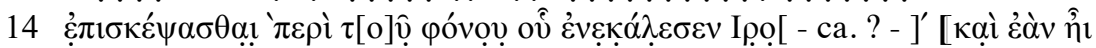

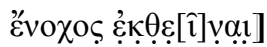

$15\left[\ldots \ldots \varepsilon \omega \varsigma \ldots[.] \ldots \ldots \kappa^{\prime}{ }^{\prime} \ldots{ }^{\prime} \ldots \ldots \ldots[\ldots \ldots]\right]$

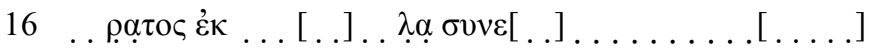

$17\left[[\ldots] \ldots \alpha_{1} \ldots \ldots[\ldots] \ldots \pi \varepsilon \rho \ldots \varepsilon, \eta \ldots[\ldots]\right]$

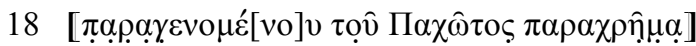

\section{Verso col. III}

Traces of nine more lines that are completely illegible, except for $\Theta \varepsilon$ o$\delta$ ó $\tau \omega !$ on the start of 1. 26. There is a vacat between 11. 25-26, and 11. 2021 have been erased.

\section{Translation}

Recto: To king Ptolemy greetings from Tham[ - - - ]. I have been wronged by Chaiapis who lives in Krokodilopolis and by her husband Pasis. On Mecheir/Pachons 7 of year 15, after an argument between me and them had arisen in the beer shop of little Memphis, I was left remaining when her husband ... later that day (s)he forced me to go up ... the aforementioned ... 35 drachmai, and when I was passing by they railed at me ... beating me with blows on whatever part of my body they could, and they tore apart my himation ... I beg you, king, if it seems good to you, to order to Aphthonetos the strategos to write to whom it concerns to investigate these things and, if my story is true, to grant me justice in the way the strategos will decide, so that, having fled to you for refuge, king, I may obtain justice. Farewell.

Verso: (col. I) ... written to him ... Please ... (col. II) about Pachos ... we summoned Pachos because Aphthonetos had written the following letter to Aphthonetos and because an accusation of murder was brought against him by ... him ... to investigate about the murder of which $\mathrm{NN}$ accused (him) and, if he would be found guilty, to procure ... ... ... as Pachos came immediately (col. III) ... Theodotos ... 


\section{Notes}

Recto

$1 \Theta \alpha \mu[\ldots]$ is the name of the petitioner, without patronymicon or any other addition. The second preserved sign can possibly also be read as an epsilon and the third one as a tau. In any case the name has to be femi-

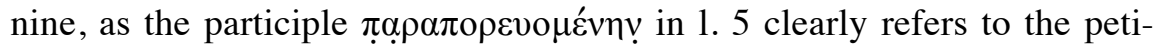
tioner. If the proposed reading of the preserved signs is correct, the peti-

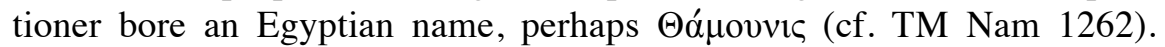

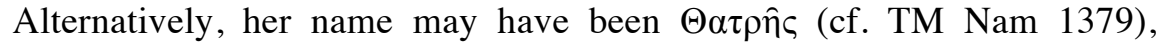
which is however only attested for the Roman period thus far.

Chaiapis (TM Nam 109) is a gender-neutral name (cf. Dem. NB 874), which is also attested for women in three Demotic Apis stelae from the Memphite Serapeion: Louvre IM 3319 (TM 54407), Louvre IM $3333=$ 4214 (TM 54410) and Vienna Kunsthistorisches Museum 5850 (TM 48448).

The construction used to indicate the place of residence of the accused

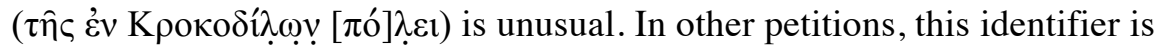

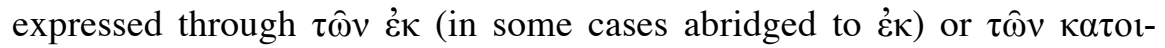

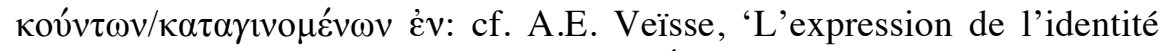
dans les pétitions d'époque ptolémaïque. Étude préliminaire', in: S. Bussi (ed.), Egitto dai Faraoni agli Arabi. Atti del Convegno "Egitto: amministrazione, economia, società, cultura dai Faraoni agli Arabi" (Milano, 7-9 gennaio 2013), Pisa/Rome 2013, p. 88.

2 The month at the beginning of this line can be read as $[\mathrm{M} \varepsilon] \chi[\varepsilon]$ !. o or $[\Pi \alpha] \chi[\grave{\omega}]$ y $\varsigma$, but the traces of the last two signs are too faint to decide which reading is correct. The strategos Aphthonetos, who is referred to in 1.8 of the recto and 11. 10-11 of the verso, was in office during the reign of Euergetes (cf. PP 236; TM Per 1229), so Mecheir 7 and Pachons 7 of year 15 would refer to 25 March and 23 June $232 \mathrm{BC}$, respectively.

A word of two or three signs seems to have been written between

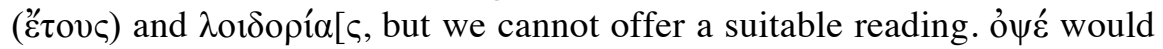
fit the context, but the preserved traces do not allow to read omikron and psi would not be perfect either.

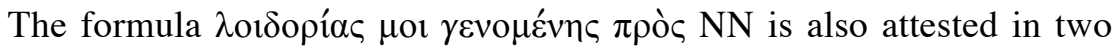
contemporary petitions from the Arsinoite nome: Mitt. Chrest. $6=$ P.Petrie

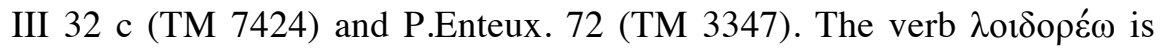


rather common in Ptolemaic petitions concerning hybris: except for the above-cited documents, see BGU III 1007 (TM 5552), BGU VI 1247 (TM 4538), P.Enteux. 25 (TM 3300), P.Enteux. 79 (TM 3354), P.Enteux. 86 (TM 3386), P.Polit. Iud. 1 (TM 44629) and P.Tebt. I 44 (TM 3680). For the use of this verb in petitions from the Roman period, see A.Z. Bryen, Violence in Roman Egypt. A Study in Legal Interpretation, Philadelphia 2013, p. 106.

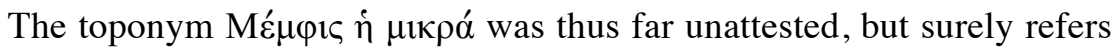
to Memphis in the Arsinoite nome (TM Geo 1343).

For alcohol consumption and disputes involving drunks in GraecoRoman Egypt, see W. Clarysse, 'Use and abuse of beer and wine in Graeco-Roman Egypt', in: K. Geus \& K. Zimmermann (eds.), Punica Libyca - Ptolemaica. Festschrift für Werner Huß, zum 65. Geburtstag dargebracht von Schülern, Freunden und Kollegen (Orientalia Lovaniensia Analecta 104), Leuven 2001, pp. 159-166.

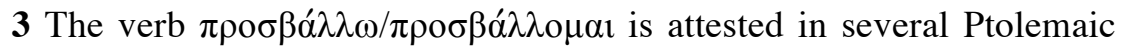
papyri. In most of these texts, the verb is used (in both active and mediopassive voice) in the sense of accepting an offer for a certain object and putting that object at the disposal of the bidder/buyer, regularly in the context of auctions: see BGU XIV 2376 (TM 3996), P.Cairo Zen. II 59161 (TM 809), P.Cairo Zen. III 59354 (TM 997), P.Eleph. Gr. 25 (TM 5857), P.Mich. XVIII 778 (TM 8772), P.Ryl. IV 563 (TM 2419), P.Tebt. III 815 (TM 7752), UPZ I 114 (TM 3506 + 5910), UPZ II 153 (TM 3554), UPZ II 154 (TM 3555) and UPZ II 155 (TM 3556). In BGU VI 1215 (TM 7306), it appears (in active voice) in the sense of turning something towards something, i.c. a war machine towards a house. In P.Hib. II 255 (TM 5213) and P.Lond. VII 1983 (TM 1545), the meaning of this verb is unclear, due to the fragmentary state of the texts. The same goes for the ex-

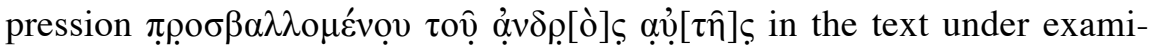
nation: none of the above-mentioned uses really suits the context.

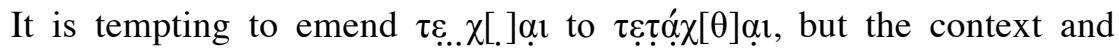
syntax are too unclear to be certain about this.

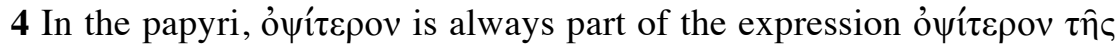
๗ँрac: see BGU I 181 (TM 8943), P.Athen. 32 (TM 10137), P.Oxy. XXXVI 2758 (TM 16549), P.Sarap. 1 (TM 17015), P.Tebt. I 230 (TM 3863), P.Tebt. II 283 (TM 42986), P.Tebt. III 793 (TM 5379), SB X 10239 (TM 16677), SB XIV 12199 (TM 14561), SB XX 14086 (TM 
14806) and SB XX 15077 (TM 14929). Such reading is impossible for the text under examination, but there is no reason to assume that ó $\psi$ í $\varepsilon \varepsilon \rho \mathrm{v}$ could not be used independently.

6 The expression $\tau \dot{v} \pi \tau \omega \pi v \gamma \mu \alpha \hat{i} \varsigma$ is also found in two other Ptolemaic petitions concerning hybris: P.Hels. I 2 (TM 5139) and P.Köln VI 272

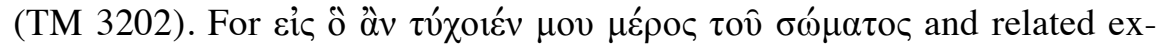
pressions, see BGU VI 1247 (TM 4538), P.Diosk. 7 (TM 44723), P.Enteux. 80 (TM 3355), P.Grenf. I 38 (TM 262), P.Gurob 8 (TM 5871), P.Hels. I 2 (TM 5139), P.Petrie II 18.2 b (TM 7401), PSI III 167 (TM 5544), PSI V 542 (TM 2164), SB X 10271 (TM 5801), SB XX 15001 (TM 8123) and SB XXVI 16800 (TM 44707).

For similar complaints concerning the tearing of clothes see BGU I 36 = Mitt. Chrest. 125 (TM 9083), P.Cair. Isid. 63 (TM 10393), P.Enteux. 79 (TM 3354), P.Erl. 36 (TM 35372), P.Grenf. I 38 (TM 262), P.Hibeh II 200 (TM 5184), P.IFAO I 16 (TM 25872), P.Lips I 37 (TM 22349) and SB IV 7449 (TM 35117).

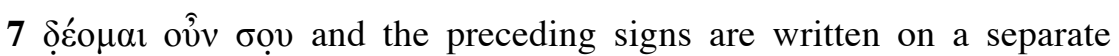
horizontal strip of papyrus that seems to have been used for repairing the papyrus.

8 In the third century BC, most enteuxeis that were nominally addressed to the king were in practice submitted to and processed by the strategos: cf. J. Hengstl, 'Petita in Petitionen gräko-ägyptischer Papyri', in: G. Thür \& J. Vélissaropoulos-Karakostas (eds.), Symposion 1995: Vorträge zur griechischen und hellenistischen Rechtsgeschichte, Cologne 1997, p. 271; H.J. Wolff, Das Justizwesen der Ptolemäer, second edition, Munich 1970, pp. 9 and 17. In these petitions in the name of the king (Eis

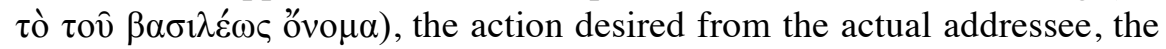
strategos, is always expressed in an indirect way: the king has to order the strategos to do something ( $\left.\pi \rho 0 \sigma \tau \alpha{ }^{\prime} \xi \alpha \iota \mathrm{NN} \tau \hat{\omega} \iota \mathrm{\tau} \tau \rho \alpha \tau \eta \gamma \hat{\omega} \iota---\right)$. Presumably, the enteuxis under examination here was processed in the same way: the petition was styled as an enteuxis to the king but went directly to Aphthonetos. The appearance of the same strategos in the draft on 11. 10-11 of the verso strengthens this hypothesis.

The request 'to write to whom it concerns' ( $\gamma \rho \alpha \dot{\psi} \psi \alpha \mathbf{o}$ oí $\kappa \alpha \theta \eta \dot{\kappa} \kappa \varepsilon 1)$ is attested in one other enteuxis from this period (P.Enteux. 6 [TM 3283]) and eight hypomnema petitions from the second century BC (P.Dryton 33 bis [TM 252], P.Erbstreit 16 [TM 156], P.Tebt. III 796 [TM 5381], P.Tebt. 
III 957 [TM 7987], P.Tebt. III 958 [TM 5473], P.Tor. Choach. 4 [TM 3593], P.Tor. Choach. 5 a [TM 3594] and P.Tor. Choach. 5 b [TM 3595]).

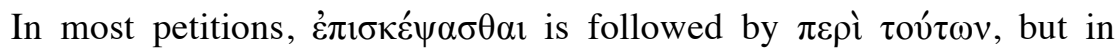
P.Hibeh II 201 (TM 5185) the verb is also combined with $\tau \alpha \hat{\tau} \tau \alpha$.

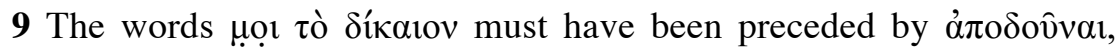

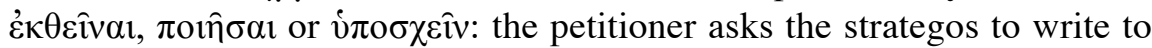
(a) certain official(s) to do justice to him.

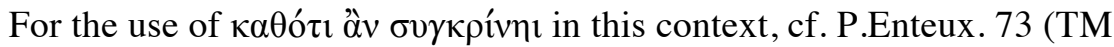
3348), P.Enteux. 76 (TM 3351), P.Enteux. 79 (TM 3354) and P.Sorb. III 104 (TM 121857). Normally this expression is followed by a name, but a similar construction with o $\sigma \tau \rho \alpha \tau \eta \gamma$ ó is found in P.Enteux. 79: ӧ $\pi \omega \varsigma$---

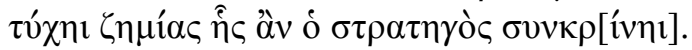

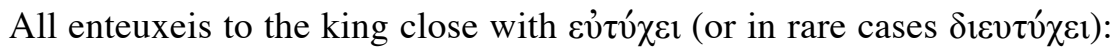
cf. A. Di Bitonto, 'Le petizioni al re', Aegyptus 47 (1967), p. 55. This closing may have been added at the end of this line or below in a separate tenth line.

Verso

1 Curiously, this line does not seem to be the beginning of the report: someone who has already been named is referred to with $\alpha v[\tau] \hat{\omega} 1$. It is difficult to make sense of the arrangement of this draft.

9 For other attestations of the name П $\alpha \chi \hat{\omega} \varsigma$, see TM Nam 4777. Perhaps

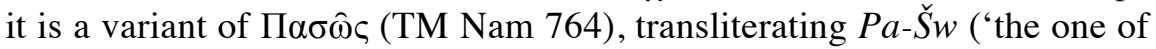
Shu').

14 I $\rho$ [ - ca. ? - ] is the name of the party who accused Pachos of

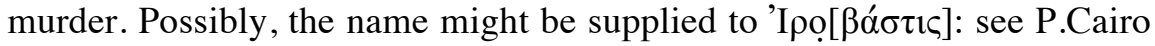
Zen. II 59261 (TM 905), P.Cairo Zen. III 59325 bis (TM 970), P.Count 6 (TM 4367), P.Count 27 (TM 7771), P.Count 35 (TM 7774), P.Count 37 (TM 7786), P.Count 38 (TM 7776) and P.Lond. VII 2002 (TM 970) for this name. The traces after $\dot{v} \pi[$ ó] on 1.12 are too faint to attempt to read the same name there. 